To cite: T Kondo 'Socio-economic rights in Zimbabwe: Trends and emerging jurisprudence' (2017)

\title{
Socio-economic rights in Zimbabwe: Trends and emerging jurisprudence
}

\author{
Tinashe Kondo* \\ Associate Lecturer, Department of Mercantile and Labour Law, Faculty of Law, \\ University of the Western Cape, South Africa
}

\begin{abstract}
Summary
In a country such as Zimbabwe where many are deprived of opportunities and resources owing, in part, to injustices of the past, socio-economic rights are of the outmost importance. As a result, the new Constitution of Zimbabwe, adopted in 2013, expressly provides for socio-economic rights. While these are yet to be extensively tested, two cases discussed in the article illustrate the willingness of the courts to enforce these rights. In the Mushoriwa case, it is shown that state as well as non-state actors have to refrain from negatively interfering with constitutionally-protected and enforceable socio-economic rights. The Hopcik case shows that there is a positive obligation on the state, which may involve the allocation of resources, to ensure that socio-economic rights are realised. These two cases serve as a good platform from which the courts can continue to develop the jurisprudence on socio-economic rights in Zimbabwe. It is suggested that guidance in dealing with more complex socio-economic rights cases can also be obtained from South African jurisprudence, particularly from the Grootboom case.
\end{abstract}

Key words: socio-economic rights; trends; emerging jurisprudence; justiciability; institutional protection; constitutional protection; judicial enforceability; transformative constitution; Zimbabwe

BCom LLB LLM (Western Cape); tkondo@uwc.ac.za. The author expresses his gratitude to the following individuals: Obdiah Mawodza (LLD candidate, Human Rights Protection); Nyasha Katsenga (LLM candidate, Trade, Business and Investment Law); and Jennifer Isokpan (LLD candidate, Human Rights Protection), who extensively edited the preliminary drafts of this article. The author is also grateful to the Graduate Lecturing Assistant (GLA) Programme at the University of the Western Cape which funded part of the researchers' doctoral studies. The views expressed in the article do not necessarily reflect those of the GLA programme. Special thanks are also extended to the two anonymous reviewers whose comments were extremely valuable in the preparation of the article. 


\section{Introduction}

In Zimbabwean history, the year 2008 is remembered for unprecedented levels of socio-political upheaval. Politically, for the first time since independence, motions were set into action for the country to be governed under a Government of National Unity (GNU). 1 The need for the GNU came as a result of the 2008 parliamentary and presidential elections which were marred by violence. As a result of the divisive political rift, mass killings occurred, some unreported, creating social instability. ${ }^{2}$ Economically, the year 2008 marked Zimbabwe's highest ever recorded inflation rate, estimated at 231 million per cent per annum. ${ }^{3}$ Consequently, shortages of food and currency, severe poverty and price increases, amongst other challenges, became the Zimbabwean way of life. These challenges left the standard and quality of life substantially diminished. Also, as a result of the reduction in resources available to the state, the capacity to deliver basic services was limited.

In this context, the year 2008 epitomised the worst form of socioeconomic challenges in the post-colonial era. From 2008 onwards, Zimbabwe became a state in transition, awaiting the development of a more comprehensive constitution, before further democratic elections could be conducted. ${ }^{4}$ After the formation of the GNU, efforts were made to ensure that the socio-economic rights ${ }^{5}$ of

1 The negotiations for the power-sharing deal were mediated by former South African President Thabo Mbeki, from 31 July 2008, although, technically, the GNU was formed on 13 February 2009. The GNU comprised of a coalition government of the three major political parties in Zimbabwe. This union followed the signing of the Global Political Agreement (GPA) by the parties concerned.

2 See S Chan \& R Primorac Zimbabwe since the unity government (2013) 8. In this period, it is alleged that eight opposition supporters were killed, while at least 20000 people were left displaced following the destruction of their homes.

3 WJ Baumol \& AS Blinder Economics: Principles and policy (2011) 506. Some economists have argued that inflation rose higher that 231 million per cent. However, their contestations have not been accepted widely.

4 Art II of the GPA, which contained the declaration of commitment, noted: 'The parties hereby declare and agree to work together to create a genuine, viable, permanent, sustainable and nationally acceptable solution to the Zimbabwean situation and in particular to implement the following agreement with the aim of resolving once and for all the current political and economic situations and charting a new political direction for the country.' With regard to the transition, it is important to read art II together with art VI which gave effect to an agreement to draft constitutional measures. Art II acknowledged that the Lancaster House Constitution (1979) was merely an apparatus to transfer power from the colonial authority to the people of Zimbabwe and, as such, the constitution-making process would be a people-driven process. Amongst other conditions, art VI provided that a Select Committee of Parliament (with members of the representative parties) be set up to draft the constitution-making process. The draft Constitution as recommended by the Select Committee of Parliament would be subjected to a referendum.

5 Socio-economic rights are human rights related to the basic necessities of life, such as the right to food; the right to shelter; the right to education; and the right to work. See http://www.Irfzim.com/wp-content/uploads/2015/05/SimplifiedVersion-of-the-Declaration-of-Rights.pdf (accessed 13 March 2016). 
citizens were given priority. ${ }^{6}$ Hence, there was a need for a new constitution, including a seminal declaration of rights (bill of rights). This was not a desire unique to Zimbabwe, but rather a need for any society emerging from conflict or a period of struggle, such as the period of election violence Zimbabwe had just emerged from. ${ }^{7}$

In 2013, Zimbabwe finally adopted a new Constitution (Constitution of Zimbabwe), ${ }^{8}$ providing for socio-economic rights. ${ }^{9}$ After the dawn of the new Constitution, it becomes important to take stock of the state's progress in protecting and promoting socioeconomic rights, to ensure that their effects filter down to the ordinary man on the street. ${ }^{10}$ The article examines the preliminary socio-economic rights debate, outlines the international socioeconomic rights framework, assesses the constitutional protection of socio-economic rights in Zimbabwe, and evaluates the prospects and challenges for the enforcement of socio-economic rights by the Zimbabwe Human Rights Commission (ZHRC) and the courts. The article then explores the empowering nature of socio-economic rights in a transformative constitution and, lastly, a number of conclusions are offered.

\section{Preliminary socio-economic rights debate}

As has been the case in many jurisdictions, in Zimbabwe there were those vying for and against the inclusion of socio-economic rights in the Zimbabwean Constitution. ${ }^{11}$ One of the arguments for the protection of socio-economic rights in the Constitution was that Zimbabwe was a state in transition after repression. ${ }^{12}$ As a result,

6 The GNU managed to finalise the constitution-making process in 2013, ushering in a new constitutional era with a much broader protection of rights. In addition to the efforts by the GNU to constitutionalise the protection of economic, social and cultural rights, there were also efforts by civil society and the citizenry to entrench these rights into the Constitution, as evidenced by the signing of the Zimbabwe People's Charter, in February 2008, by nationals representing various cross-sections of various communities, across the length and breadth of the country. The People's Charter contained what was termed 'a justiciable Bill of Rights that recognises civil, political, social, economic, cultural and environmental rights'. See the Zimbabwe People's Charter, adopted at the People's Convention, Harare, Zimbabwe, 9 February 2008, available at http://www.kubatana.net/html/ archive/cact/080209pc.asp (accessed 13 March 2016).

7 C Heyns \& D Brand 'Introduction to socio-economic rights in the South African Constitution' (1998) 2 Law, Democracy and Development 153.

8 Constitution of Zimbabwe Amendment Act 20 of 2013.

9 Constitution of Zimbabwe (n 8 above) Ch 4.

10 The socio-economic rights in the Declaration of Rights are modelled along socioeconomic rights in the South African Bill of Rights, which arguably contains the most comprehensive constitutional protection of socio-economic rights, as well as international human rights instruments.

11 See Heyns \& Brand ( $\mathrm{n} 7$ above) 9.

12 Zimbabwe, at the time, was under a GNU, which was as a result of political violence during the 2008 elections. 
there were hazards in marginalising socio-economic imperatives. ${ }^{13}$ The argument espoused socio-economic rights as a moral prerogative in the theory of justice. ${ }^{14}$

Another argument in favour of socio-economic rights to be included in the Constitution of Zimbabwe was that it would be an important step towards the adoption of a rights-based approach to social policy. ${ }^{15}$ Herein, the inclusion of socio-economic rights would ensure that the underpinning rights in regional and international human rights instruments, such as the Universal Declaration of Human Rights (Universal Declaration), the International Covenant on Economic, Social and Cultural Rights (ICESCR) and the African Charter on Human and Peoples' Rights (African Charter), were respected and promoted. ${ }^{16}$ The inclusion of socio-economic rights in the Constitution of Zimbabwe would merely ensure the domestic accountability of Zimbabwe's obligations to already-accepted and ratified human rights treaties, rather than the extension of existing commitments, in addition to those already in existence. ${ }^{17}$ In terms of these human rights instruments, socio-economic rights are the indispensable and inalienable rights of all human beings. ${ }^{18}$

Another related argument was that, in Zimbabwe, the protection of socio-economic rights was a necessity because the nation was recovering from an unpalatable period of hyper-inflation in which many citizens were subjected to deplorable living conditions. ${ }^{19}$ Herein, at least half the population was dependant on food aid and many were exposed to hunger and chronic malnutrition. ${ }^{20}$ Furthermore, almost three million people were affected annually by malaria, and nearly 100000 by cholera, with at least 4000 fatalities. $^{21}$ In a report providing for options for the constitutional protection of socio-economic rights, the Zimbabwean Lawyers for Human Rights and its partners noted: ${ }^{22}$

People around the world, including in Zimbabwe, face levels of deprivation that undermine their ability to live with dignity. Hunger, homelessness, lack of education and preventable disease are not simply social problems

13 I Muvingi 'Sitting on powder kegs: Socio-economic rights in transitional societies' (2009) 3 The International Journal of Transitional Justice 163. The argument, therefore, was that the constitutional protection of socio-economic rights was a transitional justice imperative.

14 Muvingi (n 13 above) 3.

15 T Masuka 'The new Constitution of Zimbabwe and its implications for social workers' (2014) 2 Journal of Social Welfare and Human Rights 29.

16 For a detailed discussion, see Masuka (n 15 above) 29.

17 http://hrp.law.harvard.edu/wp-content/uploads/2009/08/Zimbabwe_6.23.09.pdf (accessed 13 March 2016).

18 See, eg, the Universal Declaration, Preamble; arts 1, 2, 17, 22, 25 \& 27.

19 http://hrp.law.harvard.edu/wp-content/uploads/2009/08/Zimbabwe_6.23.09.pdf (accessed 13 March 2016).

20 As above.

21 As above.

22 As above. 
caused by inadequate resources but can also be violations of international legal obligations to respect, protect and fulfil fundamental human rights. Governments have a responsibility to respond and ameliorate these violations, which threaten principles of human dignity.

One of the most significant arguments in favour of constitutional socio-economic rights was that they were indivisible, interdependent and interrelated to civil and political rights. Those in favour of this argument were of the view that socio-economic rights formed part of a larger network of rights which were symbiotic and mutually reinforcing. ${ }^{23}$ The substance of their argument was based on the fact that, without socio-economic rights, civil and political rights would have been of a purely nominal character. ${ }^{24}$ Conversely, without civil and political rights, socio-economic rights would not be sustainable. ${ }^{25}$ Therefore, the standalone civil and political rights in the Lancaster House Constitution were purely nominal, and had to be pursued in synergy with socio-economic rights.

Apart from the arguments in favour of the constitutional protection of socio-economic rights, there were also arguments against the constitutional protection of socio-economic rights as justiciable fundamental rights. These arguments are couched within the liberal consensus on universal human rights, namely, that there is a hierarchy of rights, with civil and political rights at the top of this hierarchy. ${ }^{26}$ According to Evans, this argument stems from the fact that civil and political rights impose a 'negative obligation' (demanding forbearance), while socio-economic rights impose a 'positive obligation' (demanding a redistribution of resources). ${ }^{27}$ Therefore, it would seem that civil and political rights would take the apex position in the hierarchy as they are 'an easy way out', because they are easier to guarantee. This is unlike socio-economic rights that demand the mobilisation and rearrangement of national resources to assist those who cannot provide the material means for a decent life for themselves. ${ }^{28}$ In this case, socio-economic rights remain aspirational rather than judicially-enforceable rights. ${ }^{29}$

For example, the initial drafters of the draft Zimbabwean Constitution (Kariba Draft Constitution) were of the view that socioeconomic rights were not fundamental rights. They felt that socioeconomic rights rather were national objectives. ${ }^{30}$ Hence, in the Kariba Draft Constitution, socio-economic rights appeared as national

\footnotetext{
23 As above.

24 Annotations on the Text of the Draft International Covenant on Human Rights, prepared by the UN Secretary-General, UN Doc A/2929, 19557.

25 As above.

26 T Evans 'A human right to health' (2003) 23 Third World Quarterly 200.

27 As above.

28 S Liebenberg Socio-economic rights: Adjudication under a transformative constitution (2010) 191.

29 I Trispiotis 'Socio-economic rights: Legally enforceable or just aspirational' (2010) 8 Opticon 18261.

30 Annexure B to the Kariba Draft Constitution, Chapter II, Part 2.
} 
objectives that would guide all organs of state and government, including local government. ${ }^{31}$ Consequently, in creating and executing their policy towards the creation of a just, free and democratic society, all arms of government had to take into account the socio-economic objectives. The questionable challenge, however, to socio-economic objectives was that they were directory in nature. ${ }^{32}$ This meant that socio-economic objectives were desirable but still optional. ${ }^{33}$ The failure by an arm of government to comply with the socio-economic objectives would, therefore, at most result in a penalty, fine, review, revision or further compliance. ${ }^{34}$ Thus, the main problem with the placement of socio-economic rights as socioeconomic national objectives in the Constitution of Zimbabwe was that they would not be mandatory. ${ }^{35}$

\section{International human rights instruments}

The Universal Declaration contains both socio-economic rights and civil and political rights. ${ }^{36}$ Socio-economic rights are encompassed in articles 16 and 22 to 27 of the Universal Declaration. ${ }^{37}$ These provisions entitle the right to marry, to have a free choice in marriage and to found a family; 38 the right to choose employment, and to form labour unions; ${ }^{39}$ the right to rest and leisure, including reasonable limitation to working hours; ${ }^{40}$ the right to a standard of living adequate for health and well-being; ${ }^{41}$ the right to education; ${ }^{42}$ and the right to participate freely in the cultural life of the community,

31 Kariba Draft Constitution, Chapter II, Part 2. Secs 25, 28, 29, 30 \& 31 of the Kariba Draft Constitution dealt with work and labour relations, education, shelter, health services and social welfare, respectively. Sec 22(1)(c) of the Kariba Draft Constitution, the national objective on children, also contained socio-economic provisions, specifically for children.

32 Kariba Draft Constitution, sec 14 (nature of objectives).

33 AB Kafaltiya Interpretation of statutes (2008) 105.

34 As above.

35 The Kariba Draft, thus, offered weak constitutional protection of socio-economic rights as national objectives. Interestingly, however, despite the fact that the most socio-economic rights contained in the Constitution as socio-economic objectives, the right to agricultural land acquired for resettlement and other persons was contained in the Kariba Draft Constitution as a fundamental right together with the right to property. There have been arguments that these rights could be excluded from socio-economic rights, if the guiding principle is to look at socioeconomic rights as contained in the ICESCR. This is despite the fact that, eg, the right to property is a traditional economic right. See JA Mavedzenge \& DJ Coltart A constitutional guide towards understanding Zimbabwe's fundamental socioeconomic and cultural human rights (2014) 12, for a deeper discussion.

36 See I Merali \& V Oosterveld Giving meaning to economic, social and cultural rights (2011) 1 .

37 Arts 16, 22, 23, 24, 25, 26 \& 27 Universal Declaration.

38 Art 16 Universal Declaration.

39 Art 23 Universal Declaration.

40 Art 24 Universal Declaration.

41 Art 25 Universal Declaration.

42 Art 26 Universal Declaration. 
to enjoy arts and to share in scientific development. ${ }^{43}$ Article 22 denotes that the realisation of these socio-economic rights is indispensable to the dignity of a person. ${ }^{44}$ Accordingly, socioeconomic rights must be realised through national effort and international co-operation dependant, however, on the organisation and resources of each state. ${ }^{45}$

Over the years, the Universal Declaration has evolved to become the cornerstone of international human rights law, ${ }^{46}$ despite its nonbinding nature. ${ }^{47}$ The norms crystallised in the Universal Declaration were articulated in subsequent legally-binding treaties, such as the ICESCR; the International Covenant on Civil and Political Rights (ICCPR); the Convention on the Elimination of All Forms of Discrimination Against Women (CEDAW); the Convention on the Rights of the Child (CRC); and the International Convention on the Elimination of All Forms of Racial Discrimination (ICERD).

With regard to socio-economic rights, the ICESCR is the most relevant treaty in protecting these rights. In general, the Preamble to the ICESCR states:

[I]n accordance with the Universal Declaration of Human Rights, the ideal of free human beings enjoying freedom from fear and what can only be achieved if conditions are created whereby everyone may enjoy his economic, social and cultural rights, as well as well as his civil and political rights ...

The Preamble of the ICESCR captures the idea that, ultimately, the enjoyment of socio-economic rights is intricately connected to freedom. Without freedom, there is no chance that an individual may enjoy her socio-economic rights, let alone her civil and political rights. Hence, fundamental rights and freedoms are interdependent and interconnected. Although the Preamble is not binding, it encapsulates the spirit of the ICESCR. ${ }^{48}$

More specifically, the ICESCR contains provisions that bestow socioeconomic rights. It notes that everyone has the right to work in just

43 Art 27 Universal Declaration.

44 Art 22 Universal Declaration.

45 As above.

46 See eg S Joseph \& A McBeth (eds) Research handbook on international human rights law (2010) 2; M Karavias Corporate obligations under international law (2013) 75; L Cotula Human rights, natural resources and investment law in a globalised law: Shades of grey in the shadow of the law (2012) ch 2.

47 The Universal Declaration was not adopted by the General Assembly as a legallybinding instrument. Arguably, its contents have, however, been accepted as norms of customary international law and are viewed by some as evolving customary law. There have been arguments that the contents of the Universal Declaration have now been accepted as fundamental principles of international law and, as such, no deviation from these principles would be permissible. This is, however, a debate that falls outside the scope of this article. See Joseph \& McBeth (n 46 above) 2 and Karavias (n 46 above) 2.

48 See, generally, R O'Keefe \& CJ Trans The United Nations Convention on Jurisdictional Immunities of States and Their Property: A commentary (2013) 30. 
and favourable conditions; ${ }^{49}$ the right to form or join a trade union of his or her choice; $^{50}$ the right to social security (including social insurance) ${ }^{51}$ the right to protection of the family; ${ }^{52}$ the right to an adequate standard of living (inclusive of adequate food, clothing, housing and incessant enhancements of living conditions); ${ }^{53}$ the right to the highest attainable standard of physical and mental health; ${ }^{54}$ and the right to education (free primary education, the progressive introduction of free secondary education, and accessible higher education, progressively made free). ${ }^{55}$

Moreover, each member state to the ICESCR should to the highest possible extent of its available resources, individually or through international co-operation, seek to progressively achieve the full realisation of socio-economic rights. ${ }^{56}$ This entails that a member state can use all appropriate means, including the promulgation of new legislation, to fulfil socio-economic rights. ${ }^{57}$ Importantly, however, socio-economic rights may be subject to limitations, only to the extent necessary, in order to ensure the proper functioning of a democracy. ${ }^{58}$

Apart from the ICESCR, the African Charter also is useful as it is the African vanguard for the promotion of fundamental rights and freedoms. The African Charter draws inspiration from other international human rights instruments protecting socio-economic rights, such as the ICESCR. ${ }^{59}$ The Charter recognises that without

49 Art 7 ICESCR.

50 Art 8 ICESCR.

51 Art 9 ICESCR.

52 Art 10 ICESCR.

53 Art 11 ICESCR.

54 Art 12 ICESCR.

55 Art 13 ICESCR.

56 Art 2 ICESCR.

57 As above.

58 Art 4 ICESCR. Eg, sec 86 of the Constitution states that fundamental rights and freedoms guaranteed in the Declaration of Rights must be exercised reasonably. The section notes that these rights may be limited only in terms of the law of general application to the extent that such a limitation is reasonable, necessary and justiciable in an open and democratic society. This limitation can occur in the interests of defence, public safety, public order, public morality, public health, regional or town planning or the general public interest. Sec 86(3) lists rights which can never be limited. However, this list only consists of civil and political rights. Before any right is limited, it must be examined whether there are not any less restrictive means to achieve the purpose. In addition, the relationship between the limitation and its purpose must be reviewed.

59 Other instruments from which the African Charter draws inspiration include the Universal Declaration; the ICCPR; the ICERD; the CEDAW; the CRC; the International Convention on the Protection of the Rights of all Migrant Workers and Members of their Families; the Convention on the Rights of Persons with Disabilities; the European Social Charter; the European Convention for the Protection of Human Rights and Fundamental Freedoms; the American Declaration of the Rights and Duties of Man; and the American Convention on 
socio-economic rights, a person's dignity is endangered. ${ }^{60}$ Individuals are then exposed to numerous threats to their survival and well-being, including marginalisation and economic impoverishment. ${ }^{61}$ Therefore, in providing for socio-economic rights, member states must take into account the entire way of life of their people. ${ }^{62}$

In addition, the African Charter entrenches the freedom of profession; ${ }^{63}$ the right to property; ${ }^{64}$ the right to work; ${ }^{65}$ the right to health; ${ }^{66}$ the right to education; ${ }^{67^{\prime}}$ the right to housing; ${ }^{68}$ the right to social security; ${ }^{69}$ the right to food; ${ }^{70}$ the right to water and sanitation; ${ }^{71}$ and the right to protection of the family. ${ }^{72}$ The rights guaranteed in the African Charter, however, are not all the rights guaranteed in the ICESCR. Some of the rights in the ICESCR are implied in the African Charter. For example, in Social and Economic Action Centre (SERAC) \& Another $v$ Nigeria, ${ }^{73}$ the African Commission on Human and Peoples' Rights (African Commission) held that the rights to food and shelter were implicit in the African Charter. ${ }^{74}$ This was reiterated in the Tunis Reporting Guidelines. ${ }^{75}$

Member states must ensure that socio-economic rights are available, adequate, accessible (physically and economically) and acceptable. $^{76}$ The African Charter imposes obligations on member states to respect, protect, promote and fulfil socio-economic rights. ${ }^{77}$ The fulfilment of socio-economic rights nevertheless is subject to available resources and progressive realisation. ${ }^{78}$ There are, however, minimum core obligations with which the state must comply. ${ }^{79}$ As far as possible, each member state must maintain the minimum level of

Human Rights and the Additional Protocol to the American Convention on Human Rights in the area of Economic, Social, and Cultural Rights. See State Party Reporting Guideline for Economic, Social and Cultural Rights in the African Charter on Human and Peoples' Rights (Tunis Reporting Guidelines), adopted 24 November 2011. See also http://www.achpr.org/sessions/51st/resolutions/ 223/ (accessed 13 March 2016).

60 Tunis Reporting Guidelines (n 59 above) 6.

61 As above.

62 As above.

63 Art 8 African Charter.

64 Art 14 African Charter.

65 Art 15 African Charter.

66 Art 16 African Charter.

67 Art 17 African Charter.

68 Arts 14, $16 \& 18(1)$ African Charter.

69 Arts 4, 5, 6, 15, 16, 18(1), (2) \& (4) African Charter.

70 Arts 4, $16 \& 22$ African Charter.

71 Arts 4, 5, 15, 16, 22 \& 24 African Charter.

72 Art 18(1) African Charter.

73 (2001) AHRLR 60 (ACHPR 2001).

74 Judgment paras 64-66 \& 59-63.

75 Tunis Reporting Guidelines (n 59 above) 48-53.

76 Tunis Reporting Guidelines 10-11.

77 Tunis Reporting Guidelines 11.

78 Tunis Reporting Guidelines 12.

79 Tunis Reporting Guidelines 3. 
socio-economic rights in the African Charter. ${ }^{80}$ Whether or not the state has resources, the minimum core obligations cannot be dispensed with. ${ }^{81}$ In addition, there also is an immediate obligation on states to take steps towards the realisation of socio-economic rights, through the implementation of a quantifiable national plan of action. States should also guard against any measure(s) that may affect the enjoyment of socio-economic rights. ${ }^{82}$

Notwithstanding the above, states should ensure that individuals have ready access under domestic law to effective remedies and redress. ${ }^{83}$ The Tunis Reporting Guidelines detail how these rights should be interpreted and applied, making the African Charter a practical document for the protection of socio-economic rights in Africa. ${ }^{84}$

From the above discussion, it may be noted that international human rights instruments are paramount to the protection of socioeconomic rights. Equally important, however, is the status of these instruments in the domestic legal system. The 2013 Constitution, in contradistinction to the Lancaster House Constitution, provides clarity on the status of international documents. Section 327 of the Constitution states that ${ }^{85}$

[a]n international treaty which has been concluded or executed by the President or under the President's authority (a) does not bind Zimbabwe until it has been approved by Parliament; and (b) does not form part of the law of Zimbabwe until it has been approved by an Act of Parliament.

Put more simply, international treaties in Zimbabwe are binding only once they have been enacted into law by parliament, with the President's authority. ${ }^{86}$ Important also is the fact that the state is enjoined in section 34 of the Constitution to ensure that all international agreements to which Zimbabwe is a party are incorporated into domestic law. ${ }^{87}$

To date, Zimbabwe has signed and ratified most of the key human rights instruments, ${ }^{88}$ but is yet to domesticate these through national

80 Tunis Reporting Guidelines 13.

81 Should a state fail to comply with the minimum core obligations, it must be able to prove that it has allocated all available resources towards meeting the minimum core obligations.

82 Tunis Reporting Guidelines (n 59 above) 14.

83 Tunis Reporting Guidelines 14.

84 There are, however, other instruments, but for the purpose of this article, the discussion has been focused on the Universal Declaration, the ICESCR and the African Charter, as the most robust documents dealing with socio-economic rights.

85 Sec 237 Constitution of Zimbabwe.

86 http://www.academia.edu/4690926/The_Application_of_International_Law_in_Zi mbabwe_in_light_of_the_New_Constitution_and_the_Doctrine_of_National_Sove reignity (accessed 29 March 2017).

87 Sec 34 Constitution of Zimbabwe.

$88 \mathrm{Eg}$, the African Charter on the Rights and Welfare of the Child; the ICCPR, the Protocol to the African Charter on Human and Peoples' Rights on the Rights of 
law to ensure their full implementation. ${ }^{89}$ Most notably, and in connection with socio-economic rights, Zimbabwe has not domesticated the African Charter and the ICESCR. ${ }^{90}$ The implication of this in a dualist state, ${ }^{91}$ such as Zimbabwe, is that citizens cannot claim rights or protections which are provided for by these treaties as they have not been made part of national law through an Act of Parliament (as required by section 327 of the Constitution). There is, therefore, an urgent need to add these instruments to the government's 'list of international instruments for which domesticating Bills are required'. 92 The ongoing process of aligning old laws with the new Constitution could also be used as a platform to kick-start this process. ${ }^{93}$

In addition, Zimbabwe has not accepted the jurisdiction of the African Court on Human and Peoples' Rights (African Court) or made a declaration under article $34(6)$ to the Court Protocol. ${ }^{94}$ In addition to this, Zimbabwe has not become a state party to the Optional Protocol to the ICESCR. This creates numerous challenges in terms of protecting socio-economic rights. Most importantly, this limits the avenues for claimants of rights to have forums where they can seek recourse in the case of a violation of their rights.

An interesting juxtaposition can be found in the way in which customary international law and international treaties are dealt with in terms of the Constitution. In terms of section 326 of the Constitution, customary international law is deemed to be a part of Zimbabwean law unless it is inconsistent with the Constitution or an Act of Parliament. ${ }^{95}$ This is unlike international treaties which need to be incorporated by an Act of Parliament. The implication of this is that if a case is brought on the basis of a violation of a principle of customary international law, the courts can rely on customary international law as it is deemed part of the law. Customary international law in Zimbabwe, therefore, is more than merely a source of interpretation.

Women in Africa; the ICERD; and CEDAW.

89 A Hellum \& HS Aasen (eds) Women's human rights: CEDAW in international, regional and national law (2013) 474.

90 https://www.newsday.co.zw/2015/12/12/zim-urged-to-domesticate-humanrights-treaties/ (accessed 4 April 2017). In 2013, the former Minister of Justice, Patrick Chinamasa, disturbingly noted that there were no proper records of the treaties the country had signed and ratified to facilitate domestication.

91 A dualist state is one which views international law and domestic law as two separate orders. For international law to be binding in such a system, it must, therefore, be domesticated via legislative measures. Sec 327 of the Constitution of Zimbabwe concretises Zimbabwe's position as a dualist state. See http:// www.kas.de/upload/auslandshomepages/namibia/HumanRights/ bangamwabo.pdf (accessed 5 April 2016).

92 http://thezimbabwean.co/2017/03/zimbabwe-human-rights-commission-report/ (accessed 5 April 2017).

93 http://archive.kubatana.net/docs/demgg/ciz_crisis_report_issue_243_131203.pdf (accessed 5 April 2017).

94 As above.

95 Sec 326 Constitution of Zimbabwe. 
As regards international treaties, agreements and conventions, a case for the violation of these would only be successful if such treaty, convention or agreement has been incorporated into domestic law by an Act of Parliament.

\section{Constitutional protection of socio-economic rights}

The Constitution of Zimbabwe is the supreme law of the land. ${ }^{96}$ It provides a 'yardstick for determining lawful government action and protecting individual rights'. ${ }^{97}$ It also embodies the need to entrench democracy, good, transparent and accountable government as well as the rule of law. ${ }^{98}$ Furthermore, the Constitution embeds the commitment to uphold and defend fundamental human rights and freedoms. 99

Chapter 4 of the Constitution of Zimbabwe, the Declaration of Rights, expressly provides for socio-economic rights. ${ }^{100}$ These include the freedom of profession, trade or occupation; ${ }^{101}$ labour rights; ${ }^{102}$ property rights; ${ }^{103}$ the rights to agricultural land; ${ }^{104}$ the right to education; ${ }^{105}$ the right to healthcare; and the right to food. ${ }^{106}$ As a result, considerable constitutional protection of socio-economic rights is attained. ${ }^{107}$

These rights impose upon the state an obligation to respect, promote and fulfil them. ${ }^{108} \mathrm{~A}$ similar obligation also is imposed on non-state actors through the horizontal application of the Bill of Rights. ${ }^{109}$ This is so because many of the provisions in the Constitution would be superfluous if non-state actors could not be held accountable to constitutional mandates. ${ }^{110}$ For instance, the right to safe, clean and potable water in section $77(a)$ of the

96 Sec 2(1) Constitution of Zimbabwe.

97 http://www.justice.gov.za/legislation/constitution/history/LEGAL/CP108055.PDF (accessed 5 March 2017).

98 Preamble Constitution of Zimbabwe.

99 As above. Fundamental rights and freedoms are founding values and principles to which the Constitution aspires.

100 Annex C to the Lancaster House Agreement, 21 December 1979, Southern Rhodesia Constitutional Conference held at Lancaster House, London.

101 Sec 64 Constitution of Zimbabwe.

102 Sec 65 Constitution of Zimbabwe.

103 Sec 71 Constitution of Zimbabwe.

$104 \mathrm{Sec} 72$ Constitution of Zimbabwe.

105 Sec 75 Constitution of Zimbabwe.

$106 \mathrm{Sec} 77$ Constitution of Zimbabwe.

107 T Chivuru 'Socio-economic rights in Zimbabwe's new Constitution' (2014) 36 Strategic Review for Southern Africa 118.

$108 \mathrm{Sec} 44$ Constitution of Zimbabwe.

109 As above.

110 AR Welch 'Obligations of state and non-state actors regarding the right to water under the South African Constitution' (2005) 1 Sustainable Development Law and Policy 63. 
Constitution cannot be realised if private actors such as construction companies are putting potable water to waste. ${ }^{111}$ Questions, however, remain as to whether positive obligations may also be placed upon non-state actors.

Interestingly, some socio-economic rights also are contained in Chapter 2 of the Constitution as national objectives. ${ }^{112}$ For example, section 13(3) of the Constitution provides that the state and all institutions and agencies of government must protect and enhance the right of the people, particularly women, to equal opportunities in development. This approach is different to that in the South African Constitution, which makes reference only to rights in the Bill of Rights. 113

The socio-economic rights contained in Chapter 2 of the Constitution are merely non-justiciable national objectives, which should not be conflated with justiciable Chapter 4 rights. It is also worth noting that the non-justiciable rights in Chapter 2 should, in theory, be protected by interpreting the wide justiciable rights in Chapter 4.

Commenting upon the socio-economic rights in Chapter 2, Chivuru notes that these rights place a minimum burden on the state. ${ }^{114}$ In his view, the state is not obliged to respect and promote these rights. ${ }^{115} \mathrm{He}$ reasons that as Chapter 2 contains national objectives, 'it would create a political and societal space for a just and democratic society'. ${ }^{116}$

The Constitution, 'in describing the rights it enshrines', in part mirrors the language used by the drafters of the South African Constitution, in an act of 'constitutional borrowing'. It uses inclusive language such as 'everyone has the right to' or 'the Bill of Rights applies to all law, and binds the legislature, the executive the judiciary and all organs of state'.117

The language and contents of the Zimbabwean Constitution also depict the influence of international law instruments such as the ICESCR and the African Charter, which similarly give prominence to fundamental human rights and freedoms. For instance, all the socioeconomic rights contained in the ICESCR are reflected in the Zimbabwean Constitution. These include the freedom of profession,

111 Sec 77(a) Constitution of Zimbabwe.

112 Chapter 2 Constitution of Zimbabwe.

113 Chapter 2 Constitution of the Republic of South Africa, 1996. It has been argued that the South African Constitution has the most comprehensive constitutional protection of socio-economic rights.

114 Chivuru (n 107 above) 118.

115 This is a similar argument to the one contained in the draft Constitution that provided for socio-economic objectives, a provision which was discarded in the final Constitution. See sec 2 for the implication of socio-economic objectives.

116 Chivuru (n 107 above) 118.

117 See Ch 2 of the South African Constitution. 
trade or occupation; labour rights; the right to education; the right to health care; and the right to food and water. ${ }^{118}$

However, the Constitution does not borrow from the Directive Principles of State Policy. ${ }^{119}$ The phraseology used in these two instruments is significantly different. For example, the Directive Principles speak to the provision of free and compulsory education for children while, on the other hand, the Zimbabwean Constitution alludes to free and compulsory basic education for children and higher and tertiary education. ${ }^{120}$ The language used in the Zimbabwean Constitution, therefore, is much broader than that in the Directive Principles.

While the Zimbabwean Constitution provides for the constitutional protection of socio-economic rights, this is not enough to ensure the realisation of these rights. Their enforcement needs a sound institutional framework. At the international level, most human rights instruments prescribe that states must institute domestic mechanisms or measures to protect and promote human rights. ${ }^{121}$

In Zimbabwe, there are two main institutions enforcing human rights - the ZHRC and the courts. While both institutions are important in the enforcement of human rights, it is perhaps arguable that courts have a more prominent role to play. Nonetheless, the role of the ZHRC in enforcing socio-economic rights will first be dealt with, whereafter the judicial enforcement of socio-economic rights is considered.

\section{Enforcement of socio-economic rights by the national human rights commission}

Chapter 12 of the Constitution establishes independent institutions supporting democracy, which will be referred to as 'Chapter 12 institutions'. These autonomous institutions are charged with the task of strengthening democracy in Zimbabwe through (i) support for the entrenchment of human rights; (ii) the elevation of sovereignty and the interests of the people; (iii) the advancement of constitutionalism; (iv) the elevation of accountability and transparency in public institutions; ( $v$ ) the facilitation of the adherence to democratic values and principles by all state-related actors; and (vi) the promotion of remedies for injustices. ${ }^{122}$ Notwithstanding the fact that Chapter 12 institutions must discharge their duties without fear, favour or

118 The Constitution further introduces other rights not contained in these instruments, such as the right to agricultural land.

119 http://www.constitution.org/cons/india/p04.html (accessed 27 February 2017).

120 Sec 27 Constitution of Zimbabwe.

121 L Chiduza 'The Zimbabwe Human Rights Commission: Prospects and challenges for the protection of human rights' (2015) 19 Law, Democracy and Development 148.

122 Sec 233 Constitution of Zimbabwe. 
prejudice $^{123}$ and without being subject to the direction or control of anyone, $^{124}$ their conduct must, however, be consistent with the Constitution. ${ }^{125}$ Nonetheless, in the execution of their duties, Chapter 12 institutions must be accountable to parliament to ensure the efficient performance of their functions. ${ }^{126}$

One of the institutions established in terms of Chapter 12 is the ZHRC. ${ }^{127}$ The ZHRC is a national human rights institution (NHRI) entrusted with the responsibility of, amongst other things, the protection, promotion, development and attainment of fundamental rights and freedoms at all levels of society. ${ }^{128}$ Its focus is particularly geared at the broader human rights issues related to fundamental rights and freedoms. 129

The ZHRC wields the power to at any time require any person, institution or agency, state or otherwise, to report to the Commission on what measures they have taken to protect and fulfil the rights in the Declaration of Rights. ${ }^{130}$ It may also require from any of these actors information necessary to compile a report relating to human rights to be submitted to any regional or international body, treaty or agreement to which Zimbabwe is a state party. ${ }^{131}$

In terms of section 323 of the Constitution, the ZHRC, as an independent commission, must annually submit a report to parliament via the responsible Minister. ${ }^{132}$ However, in certain instances, when the Commission believes that a particular matter should be given attention by parliament, the matter of which relates to fundamental rights and freedoms, it may through the appropriate Minister submit a report to parliament pertaining to such matter. ${ }^{133}$

The mandate of the ZHRC differs from that of its South African counterpart, the South African Human Rights Commission (SAHRC), which has a twofold mandate. ${ }^{134}$ First, its general mandate is to monitor and assess the protection and promotion of all human rights. Second, the special mandate is with respect to socio-economic rights. This mandate arose as a result of South Africa's turbulent history, which led to the disenfranchisement of the majority. In terms of this

$123 \operatorname{Sec} 235(1)(c)$ Constitution of Zimbabwe.

$124 \operatorname{Sec} 235(1)(a)$ Constitution of Zimbabwe.

$125 \mathrm{Sec} 235(1)(\mathrm{b})$ Constitution of Zimbabwe.

126 Sec 235(1)(c) Constitution of Zimbabwe.

127 Sec 242 Constitution of Zimbabwe. The ZHRC was established in 2009 under the auspices of the GNU, after the disputed 2008 elections.

128 Sec 243(1)(b) Constitution of Zimbabwe.

129 Sec 243 Constitution of Zimbabwe.

$130 \mathrm{Sec} 244(1)(a)$ Constitution of Zimbabwe.

131 Sec 244(1)(b) Constitution of Zimbabwe.

132 Such a report must be filed before the end of March of the year following that to which the report relates.

133 Sec 244(2) Constitution of Zimbabwe.

134 D Horsten 'The role played by the South African Human Rights Commission's economic and social reports in good governance in South Africa' (2006) 9 Potchefstroom Electronic Law Journal 179. 
mandate, the SAHRC requests from organs of state information pertaining to socio-economic rights. The lack of a secondary mandate of the ZHRC, as the one entrusted to the SAHRC, does not diminish the pedestal role required of the ZHRC.

According to the African Commission, NHRIs play a central role in ensuring the protection of socio-economic rights. ${ }^{135}$ The United Nations Committee on Economic, Social and Cultural Rights (ESCR Committee) notes: ${ }^{136}$

[N]ational institutions have a potentially crucial role to play in promoting and ensuring the indivisibility and interdependence of all human rights. Unfortunately, this role has too often either not been accorded to the institution or has been neglected or given a low priority by it. It is therefore essential that full attention be given to economic, social and cultural rights in all of the relevant activities of these institutions.

As a result, it is paramount that, within the functioning of NHRIs adequate regard be given to socio-economic rights in the all the undertakings of such institutions. ${ }^{137}$

The challenge that continues to hamper the proper functioning of the ZHRC is that of funding. Operations of the Commission have been hamstrung by this financial crisis, which led to the resignation of the first Chairperson of the Commission, Reg Austin. ${ }^{138}$ In the first four years of operation, the Commission had virtually no budget. ${ }^{139}$ By 2013, the government had steadily increased funding, but it still stood at a measly US $\$ 2$ million. This eased the challenges of the ZHRC, leading to increased capacity utilisation, with 62 per cent of staff posts being filled by $2014 .^{140}$ In a paper examining the prospects and challenges of the ZHRC, Chiduza concluded that for the ZHRC to effectively discharge its duties, it must be adequately funded. ${ }^{141}$

These financial challenges of the ZHRC continue despite the fact that section 322 of the Constitution specifically states that parliament, as the custodian of the legislative processes, must ensure that adequate funds are available for use by commissions, to enable them to successfully discharge their duties. This is further reinforced in section 325 of the Constitution, which resoundingly states that the state must provide sufficient funds to commissions and other institutions established in terms of the Constitution to guarantee their proper functioning. The state has to begin prioritising the appropriation of funds for the ZHRC (and other commissions and

135 Tunis Reporting Guidelines (note 59 above) 18.

136 ESCR Committee General Comment 10.

137 Horsten (n 134 above) 178-179.

138 'ZHRC hamstrung by funding: Mugwadi' The Independent 29 August 2014.

139 As above.

140 As above.

141 Chiduza (n 121 above) 174. 
constitutionally-established institutions) so that it does not have to rely on donors to cover parts of its shortfalls. ${ }^{142}$

\section{Judicial enforcement of socio-economic rights}

The courts are vested with judicial authority which is derived from the people of Zimbabwe. ${ }^{143}$ According to section 164 of the Constitution, '[t]he courts are independent and are subject only to [the] Constitution and the law, which they must apply impartially, expeditiously and without fear, favour or prejudice'. ${ }^{44}$ It is important to note some of the principles guiding the judiciary including, but not limited to, the following, that (a) justice must be done to all, irrespective of status; ${ }^{145}$ (b) justice must not be delayed and, to that end, members of the judiciary must perform their duties efficiently and with reasonable promptness; ${ }^{146}$ (c) the role of the courts is paramount in safeguarding human rights and freedoms and the rule of law. 147

The last principle above, espoused in section 165(1)(c) of the Constitution, is of particular interest to this article. Section 165(1)(c) is instructive in respect of the role of the courts in safeguarding human rights and freedoms and the rule of law. The question, therefore, that arises is what the role of the courts is in safeguarding and promoting socio-economic rights. I am of the view that the point of departure to answer this question is to first examine the meaning of judicial enforcement.

Mbazira expresses the view that judicial enforcement refers to the role of court in satisfying the transformative vision of the Constitution in moving from the socio-economic deprivation of the majority to the equitable distribution of resources. ${ }^{148}$ Another view is to look at judicial enforcement, as not only recognising the need for government to account to democratic processes, but also ensuring that accountability is possible through litigation. ${ }^{149}$ Judicial enforcement, therefore, ensures that the rights, freedoms and guarantees in the Constitution can be litigated should they be violated.

\footnotetext{
142 Currently, 30\% of the income of the ZHRC comes from the donors while the remaining $70 \%$ comes from the government.

143 Sec 162 Constitution of Zimbabwe.

144 Sec 164 Constitution of Zimbabwe.

145 Sec 165(1)(a) Constitution of Zimbabwe.

146 Sec 165(1)(b) Constitution of Zimbabwe.

147 Sec 165(1)(c) Constitution of Zimbabwe.

148 CC Ngang 'Judicial enforcement of socio-economic rights in South Africa and the separation of powers objection: The obligation to take other measures' (2014) 14 African Human Rights Law Journal 661.

149 Ngang (n 148 above) 661.
} 
The Constitution ${ }^{150}$ and Zimbabwe's commitment to international human rights instruments impose an obligation on the courts to enforce socio-economic rights. ${ }^{151}$ Therefore, when the state fails to honour its obligation to protect, promote and fulfil socio-economic rights, the court should question this failure and take measures to ensure that the state fulfils its obligations. ${ }^{152}$ According to the International Forum for Jurists: ${ }^{153}$

Courts and quasi-judicial bodies have an important role to play in the legal enforcement of economic, social and cultural rights. Judicial remedies can provide remedies in individual cases, and can directly or indirectly result in substantial changes in domestic law and policy.

According to section 85(1) of the Constitution, an aggrieved member of society can approach the court to contend an alleged or potential violation of fundamental rights and freedoms guaranteed in the Declaration of Rights (for example, a violation of socio-economic rights). In response to the contention, the court may grant appropriate relief, which may include a declaration of rights or an award of compensation. ${ }^{154}$ Mavedzenge and Coltart aver that the court may also award a prohibitive interdict, ${ }^{155}$ a mandamus, ${ }^{156}$ or a structured interdict in the case of a violation of socio-economic rights. ${ }^{157}$ In the case of legislation prohibiting the full enjoyment of socio-economic rights, the court can also order a declaration of invalidity in terms of section 175(6)(b) of the Constitution, which grants the court the discretion to make an order that is just and equitable.

Section 85(1) of the Constitution was invoked in the 2016 case of Mudzuru. ${ }^{158}$ Here, the applicants applied to the Constitutional Court in terms of section 85(1) of the Constitution asking the Court to interpret and apply constitutional provisions as they related to early

$150 \mathrm{Sec} 165(1)(c)$ Constitution of Zimbabwe.

151 See sec 3.

152 Ngang (n 148 above) 662.

153 http://www.icj.org/wp-content/uploads/2015/07/Universal-Judicial-EnforcementESCR-Geneva-Forum-Series-2-Publications-Conference-Report-2015-ENG.pdf (accessed 13 March 2016).

154 Sec 85(1)(e) Constitution of Zimbabwe.

155 A prohibitive interdict will stop or deter the ongoing violation of a right. See Mavedzenge \& Coltart (n 35 above) 17-18 for a discussion on the various remedies available.

156 As above. In this context, a mandamus could be applied to force a respondent to perform a certain action or fulfil the disputed right.

157 As above. Under a structured interdict, a perpetrator is compelled to take measures to cure the violation of a right under the direction and supervision of the court.

158 Mudzuru \& Another $v$ Ministry of Justice, Legal and Parliamentary Affairs (NO) \& Others (Const Application 79/14) [2015] ZWCC. In this case, the Constitutional Court found sec 22(1) of the Marriage Act and any law, custom and practice which authorises child marriages unconstitutional (inclusive of the Customary Marriages Act [Chapter 5: 07], to the extent that it permitted child marriages). 
child marriages. ${ }^{159}$ The Court also dealt with the question of whether the applicants had locus standi to engage in public interest ligation to enforce the rights in the Bill of Rights.

In interpreting the Bill of Rights, the Constitutional Court noted that the courts had to develop 'new clear and precise jurisprudence'.161 The Court argued that the Constitution was a transformative document that sought to create a break with the past $^{162}$ and, accordingly, had to be interpreted progressively, generously and purposefully. ${ }^{163}$ Importantly, the Court also noted that it was common cause, when interpreting the Bill of Rights, to seek guidance from international jurisprudence and international instruments, particularly those ratified by Zimbabwe. ${ }^{164}$

Accordingly, the Constitutional Court noted that, pursuant to section 44 of the Constitution, there was an obligation to protect every right in the Declaration of Rights, regardless of the socioeconomic standing of the rights bearer. ${ }^{165}$ The Court then used the following imagery: ${ }^{166}$

Like a shepherd who cannot escape liability for a lost sheep by claiming ignorance of what happened to it, the state is expected to know what is happening to fundamental rights and freedoms enshrined in Chapter 4 [Declaration of Rights]. It is under an obligation to account, in the public interest, for any infringement of a fundamental right even by a private person.

The intention of the Court in the above imagery was to show that the courts have a vested obligation to ensure that fundamental rights and freedoms can be enjoyed in practice. ${ }^{167}$ The Court further argued that section 85(1) provided an opportunity for multiple interests of different sections of society to find redress from the Court. ${ }^{168}$ The Court reasoned that the objective of such a wide representation was

159 In analysing this issue, the Court noted that, while there was no standing to bring the matter under sec $85(1)$ (a) of the Constitution, there was, however, sufficient interest under sec $85(1)(d)$, as children's rights were of a public concern. The Court, however, cautioned that, in future, the unlimited right of access offered by sec 85 could be replaced with the 'interest of justice' rule. See judgment (n 158 above) 22.

160 The second issue was whether sec 78(1) of the Constitution set the minimum marriageable age in Zimbabwe at 18. The third issue was whether sec 22(1) of the Marriages Act was invalidated by secs 78(1) and 81(1).

161 Mudzuru judgment (n 158 above) 8.

162 Mudzuru judgment 9.

163 Mudzuru judgment 8-9.

164 Mudzuru judgment 42.

165 Mudzuru judgment 12.

166 Mudzuru judgment 13.

167 Mudzuru judgment 14.

168 As above. Sec 85 of the Constitution provides that the enforcement of fundamental rights and freedoms can be done by any of the following persons, namely, (a) any person acting on their own interests; (b) any person acting on behalf of another person who cannot act for themselves; (c) any person acting as a member, or in the interests, of a group or class of persons; (d) any person acting in the public interest; (e) any association acting in the interests of its members. 
to dismantle the formal barriers in the legal system and, in so doing, to provide tangible, significant, justice for the masses. ${ }^{169}$ The Constitutional Court noted: ${ }^{170}$

The right to access justice, which itself a fundamental right, must be made available to a person who is able to, under each of the rules of standing, to vindicate the interest adversely affected by an infringement of a fundamental right, at the same time enforcing the constitutional obligation to protect and promote the right or freedom concerned.

Consistent with the judgment delivered by Chaskalson $\mathrm{P}$ in Ferrreira $\mathrm{v}$ Levin NO \& Others, ${ }^{171}$ the Constitutional Court argued for a broad approach so that rights can enjoy full constitutional protection. ${ }^{172}$ In this bid, the Court observed:

The liberation of the narrow traditional conception of standing and the provision of the fundamental right of access to justice compel a court exercising jurisdiction under [section] 85(1) of the Constitution to adopt a broad and generous approach to standing. The approach must eschew over reliance on procedural technicalities, to afford full protection to the fundamental human rights and freedoms enshrined in Chapter 4.

The judgment by Malaba DCJ in the Mudzuru case is very informative with regard to the interpretation and enforcement of fundamental rights and freedoms. The judgment illustrates the need for a broad approach to ensure that fundamental rights and freedoms are protected. As envisaged by sections 85(1)(a)-(e), anyone who feels aggrieved that their socio-economic rights are being violated can approach the courts. One could even go as far as litigating socioeconomic rights on the basis of public interest. ${ }^{173}$

The Mudzuru case underscored the resolve of the Constitutional Court in upholding fundamental right and freedoms, more broadly. However, socio-economic rights are yet to be extensively tested in Zimbabwean courts. With regard to the negative interference in socioeconomic rights, the case of Farai Mushoriwa $v$ City of Harare (Mushoriwa case) ${ }^{174}$ is worth mentioning.

The facts of the matter, which were not contested by the parties, were that the applicant was a lawful tenant occupying flat 12 of the Northcliff block of flats in the City of Harare, ${ }^{175}$ while the respondent was the City of Harare, a duly-constituted urban municipal authority in terms of the Urban Councils Act [29:15]. ${ }^{176}$ The City of Harare was the sole supplier of domestic water in the city, including to the block of flats where the applicant resided. During May 2013, the applicant

169 Mudzuru judgment 14.

170 As above.

171 CT5/95 1996 ZACC 27.

172 Mudzuru judgment (n 158 above) 15.

173 Sec 85(1)(d) Constitution of Zimbabwe.

174 (HC 4266/13) [2014] ZWHHC 195.

175 Moshoriwa judgment 1.

176 As above. 
received a bill of US $\$ 1700$ for the purported rendering of water services. ${ }^{177}$ The applicant disputed the amount in question, and that he owed any amount to the respondent. ${ }^{178}$ On 31 May 2013, the respondent then shut off the water supply of the applicant, leading to the urgent application by the applicant to the High Court.

The respondent argued that in terms of section 8 of the City of Harare's water by-law read together with '[section] 198(3) and [section] 69 of the third schedule to the Urban Councils Act it is clothed with unfettered discretion to disconnect water supplies to a citizen at will without recourse to the courts of law'. ${ }^{179}$ The counterargument of the applicant was that '[t]he by-law relied upon by the [r]espondent [w]as ultra vires section 198 as read with [section] 69(2)(e) of the third schedule to the parent Act and [section] 77 of the Constitution'.180

The applicant sought a spoliation order and an interdict as an interim measure. ${ }^{181}$ Herein, the applicant pursued the restoration of his power supply. As a final order, the applicant sought an order showing the following:

(a) the termination by the respondent of the applicant's water supply on the basis of a disputed water bill and in the absence of a court order is unlawful self-help;

(b) that the respondent and all its employees be interdicted from interfering in any way whatsoever with, disrupting or terminating the applicant's water supply without a court order;

(c) that the respondents shall pay all of the cost of the suit on the higher scale of legal practitioner and client scale only if it opposes the application.

Section 77 of the Constitution provides for the right to food and water. It states:

Every person has the right to -

(a) safe, clean and potable water; and

(b) sufficient food;

and the state must take reasonable legislative and other measures, within the limits of resources available to it, to achieve the progressive realisation of the rights set out in this section.

The High Court in this matter first noted the obligation in section 44 of the Constitution to protect fundamental rights and freedoms imposed on all persons, natural and juristic, including every institution and agency of government at every level. It observed that in this

177 Moshoriwa judgment 2.

178 As above.

179 Moshoriwa judgment 3.

180 Moshoriwa judgment 4.

181 Moshoriwa judgment 1. 
particular case, the respondent was an institution of local governance and was therefore obligated not to deny citizens water without just cause. ${ }^{182}$ It noted that the role of the courts in promoting and safeguarding fundamental rights and freedoms, as guaranteed in section $165(1)(c)$ of the Constitution, was essential to the functioning of the rule of law.

In attempting to interpret the role of the court in protecting and promoting socio-economic rights, in particular the right to water and food, the High Court quoted the words of Francis Bennion, in his book Statutory interpretation (1984), where he stated: ${ }^{183}$

A court is an agency charged with the function of exercising the judicial power of the state. Only a court as thus defined has the power authoritatively to determine what the law is, and therefore what is the legal meaning of a relevant enactment.

The High Court was of the view that Bennion's statement accorded with section 171 of the Constitution. Pursuant to section 171, the High Court has jurisdiction over all civil and criminal matters, with unlimited jurisdiction throughout the country, except in cases where the power of the Court has been expressly limited by parliament. ${ }^{184}$

The High Court noted that it had been conferred powers by the Constitution, as the supreme law of the land, to rule over this matter and subsequently to make a determination. ${ }^{185}$ Resultantly, the Court took the view that it could, therefore, not abdicate its function because of an errant and unlawful municipal by-law, which was contrary to the spirit of the Constitution as well as the enabling statute. $^{186}$

More specially, the High Court noted that section 8 of by-law 164 of 1913 was inconsistent with the Constitution and the enabling statute in more than one way. ${ }^{187}$ As a point of departure, section 8 of by-law 164 enabled the respondent to 'arbitrarily deprive citizens of their fundamental right to water without compensation contrary to [section] 85 of the Constitution which entitles an aggrieved person to appropriate compensation whenever his fundamental right has been violated'. $^{188}$ To add to that, ${ }^{189}$

in the event of a disputed bill it unlawfully confer[red] the respondent with the sole jurisdiction to arbitrarily determine the dispute without recourse to the courts of law contrary to the provisions of [section] 69 of the third schedule to the Act as read with [section] 165 (1)(c) of the Constitution. By so doing the by-law allows the [r]espondent to be the sole arbiter in its

182 Moshoriwa judgment 5.

183 As above.

184 Moshoriwa judgment 6.

185 As above.

186 As above.

187 As above.

188 As above.

189 As above. 
own case contrary to the well-established common law maxim that no one should be a judge in his own case.

Section 8 of the by-law did not serve a public function, and was rather in violation of basic legal principles (such as that the Harare City Council could be a judge in its own case). ${ }^{190}$ In the opinion of the Court it was notorious that the City Council could exercise its right to collect debts by willy-nilly barring citizens' access to water, a fundamental right, without affording them recourse to the law and courts; in clear violation of public interest, the enabling statute and the Constitution. ${ }^{191}$ The Court observed that in a similar case, City of Cape Town $v$ Strumpher (pre-2013 Constitution), ${ }^{192}$ the court had come to the same conclusion. ${ }^{193}$ The High Court then granted the interim relief, and ordered that the respondent, through his legal counsel, show why the final relief should not be granted. ${ }^{194}$

The Mushoriwa case demonstrates that when faced with a challenge to socio-economic rights, the court will not hesitate to grant appropriate relief. ${ }^{195}$ The court, therefore, showed that it has the power to adjudicate on matters concerning the infringement of socioeconomic rights without fear, favour or prejudice. ${ }^{196}$ Furthermore, the courts are alert to usurpers of power who abuse their authority to violate socio-economic rights, to the detriment of society. ${ }^{197}$ For these reasons, the courts can then be said to be custodians of the enforcement of socio-economic rights.

The Mushoriwa and Mudzuru cases both dealt with the 'negative interference of rights with enjoyment of existing rights'. However, in most instances, the challenge with socio-economic rights claims 'is mostly with enforcing positive claims', for instance, the duty of the state to provide for the guaranteeing of socio-economic rights. A good case in point is the recent case of Hopcik Investment (Pty Ltd) $v$ Minister of Environment Water and Climate and City of Harare (Hopcik (ase). ${ }^{198}$

In this case, the applicant, Hopcik Investment (Pty Ltd), sought an order compelling the respondents, the Minister of Environment, Water and Climate and the City of Harare, to supply 15000 litres of potable water per week to its premises. ${ }^{199}$ The application followed the failure by the City of Harare to supply water in the area in which the applicant's property was situated (Ballantyne Pak, Harare) for a

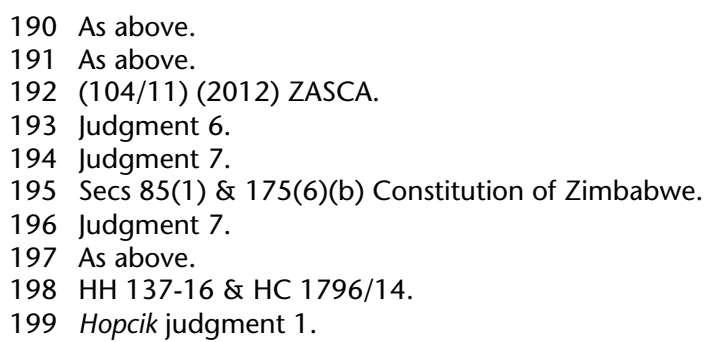


period of three years. ${ }^{200}$ In contrast, other properties in Harare had access to a constant supply of water. ${ }^{201}$

While the applicant acknowledged that the City of Harare faced certain challenges that hindered the provision of water to all residents, they were of the view that not sufficient steps had been taken to ensure the equitable distribution of water to all inhabitants. ${ }^{202}$ Further to this, the applicant submitted that the City of Harare was derelict of its duty to supply water to all residents. 203

In response to the contentions of the applicant, the City of Harare argued that it was embattled with a myriad of challenges; most notably financial constraints. ${ }^{204}$ Also, the City of Harare cited a significant growth in the urban population that resulted in the demand for water outstripping supply. ${ }^{205}$ Furthermore, the City of Harare also highlighted the need to factor in the turbulent economic climate which made it difficult to adequately maintain critical infrastructure such as water pipes. ${ }^{206}$ Finally, the City of Harare noted that erratic rainfall had also exacerbated the situation. It is against this background that the City of Harare argued that it had been unable to guarantee the applicant the minimum 15000 litres of water they sought.

As part of its arguments, the City of Harare noted that the legislature had envisioned such a situation when they drafted section 183(1) of the Urban Councils Act, ${ }^{207}$ which used the word 'may' in relation to the ability of the Council to supply water to its residents. The exact language used is as follows: ${ }^{208}$

(1) A council may provide and maintain a supply of water within or outside the council area and for that purpose the council may -

(a) in accordance with the Water Act [Chapter 20:22] take such measures and construct such works, whether inside or outside the council area, as it considers necessary for the purpose of providing and maintaining a supply of water;

(b) enter into agreements for the purchase and sale of water and for any other thing necessary in connection with the maintenance and supply of water.

The argument of the City of Harare pursuant to this provision holds weight; nevertheless, it negates the constitutional mandate in section 77 of the Constitution providing everyone with the right to water, a right in respect of which the state must take reasonable legislative and

200 Hopcik judgment 2.

201 As above.

202 As above.

203 As above.

204 As above.

205 Hopcik judgment 3.

206 As above.

207 [Chapter 29: 15].

208 Sec 183(1). 
other measures, within its resources, to progressively realise the right. While section 77 speaks generally about the state, the Preamble to Chapter 14 of the Constitution provides that there must be a devolution of power and responsibilities given to lower tiers of government so as to ensure the equitable allocation of national resources. This is reinforced in section 264 of the Constitution on the devolution of governmental powers and responsibilities.

Notwithstanding the above, both respondents submitted that they were taking steps to alleviate the dire situation. ${ }^{209}$ They averred that they had engaged various stakeholders, including investors and partners. Through these engagements, they had subsequently managed to receive loans which they hoped to utilise to ease the situation. ${ }^{210}$ In addition to this, the Minister had also signed a number of 'memorandums of understanding and agreements with different countries and construction companies with the objective of building dams, drilling of boreholes so as to improve water supply'. ${ }^{211}$ Based on these actions, the respondents hoped to see changes in the water supply in the near future. ${ }^{212}$

In looking at the arguments of both parties, the High Court noted that the right to water was the most basic of rights and was recognised as a human right by the United Nations General Assembly through Resolution 64/292 of 28 July $2010 .^{213}$ This Resolution places an obligation on states to take measures to ensure that its citizens have access to safe, sufficient, affordable, quality and physicallyaccessible water. ${ }^{214}$ To meet this mandate, state parties, therefore, have to make financial resources available so as to aid in capacity building and technology transfer. ${ }^{215}$ The High Court further noted that this right to water was also entrenched in other international instruments, such as CEDAW, the CRC and the ICESCR. ${ }^{216}$ In terms of this right to water, the Court noted that there was entitlement to access to a minimum amount of water necessary to sustain life and health. $^{217}$ To concretise this argument, the High Court noted the South African case of Mazibuko, ${ }^{218}$ where the Constitutional Court held that the entrenchment of the right of access to water was not surprising because of its centrality in human life. ${ }^{219}$

Focusing on legislation, the High Court noted that the right to water in section 77 of the Constitution was introduced as an

209 Hopcik judgment 2.

210 As above.

211 As above.

212 As above.

213 Hopcik judgment 3.

214 As above.

215 As above.

216 As above.

217 As above.

218 Mazibuko \& Others $v$ City of Johannesburg (CCT 39/09) (2009) ZACC.

219 Hopcik judgment 4. 
enshrined constitutional right in recognition of the right to water. This was in line with the UN Resolution of 28 July 2010 which placed an obligation on the state to provide water. 220

Turning to the realisation of this right, the High Court cited the primary obligation to ensure this right as being placed on the state, through the first respondent. ${ }^{221}$ However, the state had to take measures to ensure the implementation of the right, which included ceding some of the responsibility to the second respondent through the Water Act and the Urban Councils Act. ${ }^{222}$ To ensure the effectiveness of this delegation, the state had to ensure that the local authorities have enough power and resources to perform this function. 223

In conclusion, the High Court noted that the respondents had both failed to take reasonable steps to address the challenges. ${ }^{224}$ The Court further highlighted the curious disparity in the manner in which water was distributed to different residents in the town. It underscored the need to provide water in a manner which was fair and equitable to all residents. Where challenges existed in particular areas, measures had to be taken to alleviate this plight, including making use of technology. ${ }^{225}$ Consequently, the failure of the respondents was a breach of section 77 of the Constitution. The High Court then made the order that the respondents, jointly and severally, be responsible for ensuring a supply of water to the applicant's premises. ${ }^{226}$

Similar to the Mushoriwa case, the Court once again noted the need to respect and promote socio-economic rights. Differently, however, this case illustrated that there was a positive obligation on the state to ensure that socio-economic rights are met, which obligation also involves the allocation or redistribution of resources. While the Court dealt with this issue of positive enforcement of rights, there were more arguments and considerations which could have been taken into account. The High Court seems to have superficially treated the issues and marginalised broader socio-economic rights considerations. The Grootboom case is a good example of which considerations ought to be taken into account when dealing with the positive enforcement of rights. ${ }^{227}$

In this case, an application was brought by several individuals, including children, who had illegally moved onto private land as a

220 As above.

221 As above.

222 As above.

223 As above.

224 Hopcik judgment 6.

225 As above.

226 Hopcik judgment 7.

227 Government of the Republic of South Africa \& Others $v$ Grootboom Case CCT 11/00. 
result of the appalling conditions they were living in while awaiting low-cost housing. ${ }^{228}$ They were subsequently evicted and moved to a sports field where they could not erect shelters after their material had been destroyed during the eviction. On application, they were granted relief to the effect that the government had to provide them with shelter until they secured permanent accommodation pursuant to section 28(1)(c) of the South African Constitution. This decision by the High Court was then taken on appeal. The respondents argued that the right to housing was a minimum core obligation which the state had to comply with, subject to section 26. The Constitutional Court noted:229

Neither section 26 nor section 28 entitles the respondents to claim shelter or housing immediately upon demand. The High Court order ought not to have been made. However, section 26 does oblige the state to devise and implement a coherent, coordinated programme designed to meet its section 26 obligations ... The order requires the state to act to meet the obligation imposed upon it by section 26(2) of the Constitution. This includes the obligation to devise, fund, implement and supervise measures to provide relief to those in desperate need.

This case was a landmark case in the enforcement of positive socioeconomic rights. It addresses concerns that were not properly addressed, in the Zimbabwean context, in the Hopcik case (the Constitution contains a provision similar to section 26 of the South African Constitution).

First, the Grootboom case eases 'separation of powers concerns'. It is a stellar example of how the judiciary can force the executive the obligation to ensure that socio-economic rights are protected, promoted and realised. Second, and closely connected to the first, the Grootboom case debunks the myth that socio-economic rights are purely aspirational and should be left in the hands of politicallyaccountable politicians. ${ }^{230}$ From this case, the Zimbabwean courts can learn that the judicial enforcement of these rights is essential in the realisation of these rights.

Third, the Grootboom case settles polycentric arguments. These arguments centre upon the premise that courts are poorly equipped to deal with issues the consequences of which go beyond the parties involved. ${ }^{231}$ While all justiciable rights, to some degree, entail polycentric elements, scholars have noted that polycentricity is considerably high in socio-economic rights litigation. ${ }^{232}$ The Grootboom case bears testimony to the fact that the merits of these arguments are significantly limited. The Constitutional Court adequately dealt with competing arguments and inter-acting variables in enforcing the socio-economic rights of the litigants. This was

228 Hopcik judgment para 3.

229 Grootboom judgment paras 95-96.

230 Trispiotis (n 29 above) 3.

231 As above.

232 L Lazarus et al (eds) Reasoning rights: Comparative judicial engagement (2014) 320. 
notwithstanding the alleged inadequate training of judges on policy matters. The Zimbabwean courts can thus use this judgment as a benchmark to assert their competence in dealing with these issues. ${ }^{233}$ However, it should be cautioned that the curriculum of the Bachelor of Laws (LLB) degree in Zimbabwe is not as broad and interdisciplinary as that in South Africa. Furthermore, the lack of specialised interdisciplinary post-graduate legal programmes also is a cause for concern. These factors could adversely affect the enforcement of socio-economic rights in Zimbabwe. ${ }^{234}$

Fourth, Zimbabwe may also learn that the judicial enforcement of socio-economic rights reinforces the political legitimacy of policies that support this vision. ${ }^{235}$ In the Zimbabwean context, this would support controversial policies such as the Indigenisation and Economic Empowerment Policy, the Land Reform Policy and the Zimbabwe Agenda for Sustainable Socio-Economic Transformation, which focus on realising socio-economic rights of previously-marginalised individuals.

Finally, an important aspect of the Grootboom judgment was the potential effect of the internal limitation on enforcing or realising socio-economic rights. The Constitutional Court grappled with an extremely constrained budget for housing and the progressive realisation of this right. ${ }^{236}$ In approaching this challenge, the Court noted the following, that (i) what are considered as reasonable measures should be interrogated from the prism of the three spheres of government (national, provincial and local government) and in view of the Bill of Rights as a whole; ${ }^{237}$ (ii) the drafters had foresight of the fact that socio-economic rights could not be realised immediately, but this did not deprive these rights of their meaningful content; $^{238}$ and (iii) only what is possible within the current resources is expected, thus requiring a balance between goals and means. ${ }^{239}$

In Zimbabwe, Chapter 4 socio-economic rights also are constrained by similar limitations such as progressive realisation, reasonableness of measures and the availability of resources. These internal limitations, coupled with the general limitation to rights in section 87 of the Constitution, could potentially limit 'the protection and possible enforcement of Chapter 4 socio-economic rights'. This further is exacerbated by the fact that most of the socio-economic rights in the

233 See, generally, RE Kapindu 'Courts and the enforcement of socio-economic rights in Malawi: Jurisprudential trends, challenges and opportunities' (2013) 13 African Human Rights Law Journal 140.

234 See, eg, http://www.gzu.ac.zw/bachelor-of-laws-llb-honours-degree/ (accessed 5 March 2016).

235 The International Institute for Democracy and Electoral Assistance 'Social and economic rights' (2014) Constitution Building Primers 6.

236 Grootboom judgment para 14.

237 Grootboom judgment para 44.

238 Grootboom judgment para 45.

239 Grootboom judgment para 46. 
Bill of Rights are of a basic nature. An approach such as that in Grootboom could assist in restricting the challenges brought by the internal and general limitations.

\section{Empowering nature of socio-economic rights under a transformative constitution}

Socio-economic rights are empowerment rights: They allow sociallyvulnerable and marginalised individuals and groups to use the legal process in order to obtain the satisfaction of their essential socioeconomic needs. Socio-economic rights empower people who are subject to the jurisdiction of a state to demand that that state acts reasonably and progressively to ensure that all enjoy the basic necessities of life. In so doing, these rights progressively enable citizens to hold government accountable for the manner in which it seeks to hold government accountable for the manner in which it seeks to pursue the achievement of social and economic welfare and development. 240

The profound quote above from the work of Kapindu speaks to the aspirations of the nation (Zimbabwe), as seen through the national objectives in Chapter 2 and the resolve to protect fundamental rights and freedoms in Chapter 4 of the Constitution (Declaration of Rights). The Constitution of Zimbabwe came into being after a prolonged period of colonialisation in the past and, more recently, a turbulent political environment that led to the signing of the Global Political Agreement (GPA) and the creation of an inclusive government. Therefore, it was imperative that the Constitution be clothed as a transformative one. Such a constitution would aid in healing past injustices, and charting an inclusive future where all citizens could equitably enjoy the resources of the country and share in its prosperity.

In a transformative constitution, socio-economic rights allow those at the bottom of the barrel of society, who wield neither material nor political power, the opportunity to have access to adequate socioeconomic conditions. Without adequate socio-economic conditions, the poor cannot maintain their dignity. To these members of society, civil and political rights mean nothing without accompanying socioeconomic rights which, to them, are more real. For example, imagine a citizen and his family living on the banks of the Mukuvisi river in Harare. To this person, the right to vote means a chance in four or five years to change politicians who are removed from the plight he and his family bear testimony to. The protection of the right to food, for example, would be very real to them as this would determine what meal their family will or will not have. Socio-economic rights accrue quite naturally to the rich and elitist by virtue of the pedestals on

240 Kapindu (n 233 above) 126. 
which they sit in society. It is quite impossible to find a rich person who could be deprived of the right to food, as they can easily buy or, in certain instances, import the food they need for their family.

The reality of our African societies is that poverty is a scourge that is omnipresent in the lives of the majority of our people. Poverty, coupled with a lack of opportunity, significantly diminishes socioeconomic conditions. The Constitution of Zimbabwe instituted significant protection for socio-economic rights in order to mitigate the effects of poverty and the lack of opportunity. However, this is not enough as these provisions need teeth through judicial enforcement.

In a transformative constitution, such as the Constitution of Zimbabwe, the protection and legal enforcement of socio-economic rights ensure that there is equality and justice for all. Society cannot heal if the gap between rich and poor continues to widen, and the poor are left to live in abject poverty without basic socio-economic needs. The provision of socio-economic rights in the Constitution ensures that the aspirations of the founding fathers that fought for the liberation of Zimbabwe are realised. This leads to the creation of an egalitarian, prosperous and democratic society, built on the principles of freedom, equality, peace, justice and tolerance, where the country can search for new frontiers under a common destiny.

\section{Conclusion}

Zimbabwe's economic landscape is still littered with the effects of the 'white colonial regime' that disenfranchised the masses, and shifted economic power into the hands of a few (the white minority). To date, as a result of prolonged deprivation of opportunity, coupled with political misdirection, many are still deprived of their basic socioeconomic needs. While the masses are still unable to provide for themselves, a new form of black elite has emerged, leading to a twopronged elite system (black elite and white elite). A transformational constitution was an appropriate action in order to balance the economic scale of society. The Constitution seeks to create an equal society, where all can share in the resources and prosperity of the country.

The article revealed that, although there was initial resistance to include socio-economic rights as justiciable rights, the new Constitution includes judicially-enforceable socio-economic rights in the Declaration of Rights. The provision for socio-economic rights in the Constitution was shown to reinforce socio-economic rights in regional and international human rights instruments, such as the Universal Declaration, the ICESCR, the CEDAW, the CRC and the ICERD. It was shown that in terms of institutions, the ZHRC has been awarded significant powers to deal with issues relating to socioeconomic rights and fundamental rights and freedoms. The state, however, needs to appropriate more resources to the ZHRC, in order for it to operate at full capacity and discharge its mandate efficiently. 
The article showed the steadfastness of the judiciary in upholding fundamental rights and freedoms, including socio-economic rights. The Mudzuru case proved that even in public interest cases, the courts will protect and enforce any rights in the Bill of Rights. More specific to socio-economic rights, the Mushoriwa case showed that the courts would not hesitate to develop a socio-economic rights jurisprudence. Accordingly, a wide approach to the interpretation of fundamental rights and freedoms so that all rights and freedoms could be comprehensively covered was adopted in the case. The Hopcik case demonstrated that in cases of the positive enforcement of rights, the courts would not hesitate to enforce on the state its duty to mobilise resources to ensure socio-economic rights. Finally, the article suggests that, in developing socio-economic right in the future, the courts could benefit from South African jurisprudence, in particular the Grootboom case. 